\title{
Hepatoprotective Activity of Pirdot Leaves (Saurauia vulcani Korth) Ethanol Extract in Laboratory Rats (Rattus norvegicus) and Characterization of Bioactive Compounds Using a Molecular Docking Approach
}

\author{
Erlintan Sinaga ${ }^{1}$, Syafruddin Ilyas ${ }^{1 *}$ (D) Salomo Hutahaean ${ }^{1}$ (D), Panal Sitorus ${ }^{2}$ (D) \\ ${ }^{1}$ Department of Biology, Faculty of Mathematics and Natural Sciences, Universitas Sumatera Utara, Medan, Indonesia; \\ ${ }^{2}$ Department of Pharmacy, Faculty of Pharmacy, Universitas Sumatera Utara, Medan, Indonesia
}

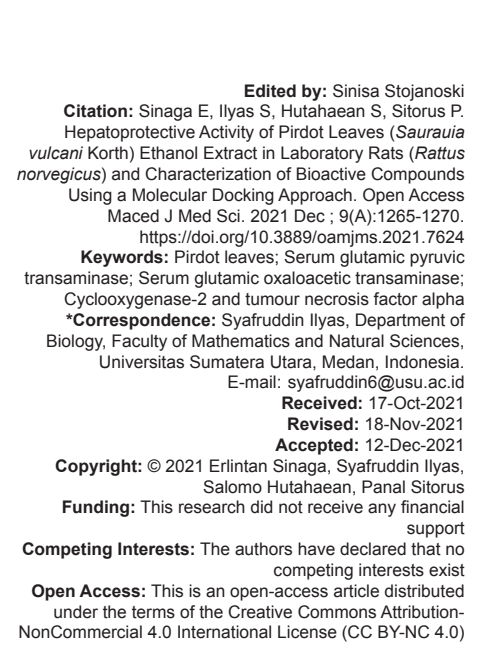

\begin{abstract}
AIM: The purpose of the research was to determine the hepatoprotective activities of bioactive compounds pirdot by in vivo and in silico study.

METHODS: In this study, the completely randomized design non-factorial was experimentally to assess the value of serum glutamic pyruvic transaminase (SGPT) and serum glutamic oxaloacetic transaminase (SGOT) and 24 adult male rats were divided into four groups: Group $\mathrm{G}_{0}$, control group; group $\mathrm{G}_{1}$, a treated group received $0.1 \mathrm{ml}$ sheep red blood cell (SRBC); group $\mathrm{G}_{2}$, a treated group received $500 \mathrm{mg}$ ethanol extract pirdot; and group $\mathrm{G}_{3}$, a group treated received $500 \mathrm{mg}$ ethanol extract pirdot and $0.1 \mathrm{ml}$ SRBC. On 31 days of treatment, the blood of all rats group was taken to value SGPT and SGOT using DiaLab kit. Furthermore, the molecular docking study was done to analyze molecular interaction of cyclooxygenase 2 (COX-2) and tumor necrosis factor alpha (TNF- $\alpha$ ).

RESULTS: The results show SGOT and SGPT value significantly $(p<0.05)$ decreased on group $G_{2}$ and $G_{3}$. Moreover, the bioactive compounds of pirdot, such as pomolic acid and ursolic acid, tend to be the potential compound on liver protection. Moreover, pomolic acid has a good binding affinity $-14.6 \mathrm{kcal} \mathrm{mol}^{-1}$ with COX-2 protein and the binding affinity of cis-3-O-p-hydroxycinnamoyl ursolic acid was $-15.1 \mathrm{kcal} \mathrm{mol}^{-1}$ associated with TNF- $\alpha$ protein.

CONLUSION: Pirdot leaves (Saurauia vulcani Korth) ethanol extract showed hepatoprotective activity in rats (Rattus norvegicus). Molecular docking approach showed that pomolic acid has a good binding affinity with COX-2 protein and TNF- $\alpha$ protein
\end{abstract}

\section{Introduction}

The liver has a very important role in the process of detoxification and excretion of various compounds in the circulatory system [1]. Liver interaction with these compounds induces an adaptive immune response that produces inflammatory cytokines such as interferon- $\gamma$ and tumor necrosis factor (TNF)- $\alpha$ [2]. Liver damage is also caused by the use of drugs and chemical compounds that are toxic [3]. In the process of metabolic decompensation, liver function is related to the immune system [4]. Furthermore, hepatocytes and kupffer cells have an important role in antigen metabolism in the liver [5]. Serum glutamic oxaloacetic transaminase (SGOT) and serum glutamic pyruvic transaminase (SGPT) values are used as indicators in evaluating liver damage. SGOT is an enzyme found in the cytoplasm and mitochondria of liver cells. SGOT levels can be used to assess the extent of liver damage. Meanwhile, SGPT is an enzyme that is produced when there is damage to liver cells by seeing an increase in SGOT levels in blood serum [6]. The increase in SGPT or aspartate aminotransferase is due to changes in permeability or damage to the liver cell walls. Thus, it is used as a marker for impaired hepatocellular liver cell integrity. Secondary metabolites produced by plants are currently one of the alternatives in the treatment of liver damage [7]. Saurauia vulcani Korth is a family Actinidiaceae that has secondary metabolites of polyphenols, flavonoids, steroids, saponins, tannins [8], and triterpenoid [9]. According to a previous study, pirdot leaf flavonoid compounds are genistein isoflavones that function to reduce glucose levels and glucose tolerance in the body, heal wounds, and increase insulin levels in the body [10]. High flavonoids in pirdot leaves tend to be hepatoprotective. This study aims to determine the levels of SGOT, SGPT, and liver morphology from ethanol extract of pardon leaves and to predict molecularly the interaction of Saurauia secondary metabolites with proteins involved in oxidative stress and inflammation in the liver. 


\section{Materials and Methods}

\section{Preparation of test animals}

Twenty-four laboratory rats (Rattus norvegicus) aged 3 months, weighing 150-200 g, were obtained from the Pharmacy Laboratory, Institut Teknologi Bandung. They were then acclimatized at a temperature of $24 \pm 27^{\circ} \mathrm{C}$ for a week in the Pharmacy Laboratory, Universitas Padjajaran, Bandung. Then, the mice were treated for 30 days and given food and ad libitum water.

\section{Preparation of pirdot leaf ethanol extract Saurauia leaf ethanol extract (EES)}

Six km of pirdot leaves, obtained from North Tapanuli (North Sumatra, Indonesia), were dried and mashed to produce pirdot leaf flour. A $500 \mathrm{~g}$ of pirdot leaf flour were put into two places, $250 \mathrm{~g}$ each, and added with distilled ethanol (1.875 mL/place). Pirdot flour was then soaked for $5 \mathrm{~s}$ and was stirred twice a day. The filtrate obtained was separated using filter paper to obtain $2.1 \mathrm{I}$ with the addition of ethanol further to get 3 I of solution. After that, the filter results were concentrated using a rotary-evaporator and left to stand in a water bath for 4 days. Fifty-one $g$ of ethanol extract of pirdot were given orally to laboratory rats $500 \mathrm{mg} / \mathrm{kg}$ for 30 days [11]. (SRBC)

\section{Preparation of sheep red blood cells}

Sheep blood as antigen was obtained from the Lembang Veterinary Laboratory, Bandung, Indonesia. Sheep blood was taken from the blood vessels in the neck as much as $5 \mathrm{~mL}$ and washed using phosphate buffered saline with a pH of 7.4 then centrifuged at $200 \mathrm{rpm}$ for 15 min. Centrifugation was carried out 3 times. Blood specimens were stored in the freezer at $-4^{\circ} \mathrm{C}$.

\section{Effect of pirdot leaf ethanol extract on SGPT and SGOT values}

The laboratory rats were anesthetized after 30 days of treatment. Blood was collected from the treated group of laboratory rats through a vein from the neck of the laboratory rats. The serum was separated by centrifugation at $2500 \mathrm{rpm}$ for $10 \mathrm{~min}$. SGOT and SGPT were analyzed by spectrophotometric measurements (Dialab, 2006, Liquid Reagents of GOT, Austria: DIALAB Production von chemish-technishen.) [12].

\section{Liver histopathology examination and} degree of hepatocyte damage

Liver pieces were washed with $0.9 \%$ saline solution and preserved with $10 \%$ formalin solution at the fixation stage which was continued at the paraffin stage with hematoxylin and eosin staining [13], [14]. The histopathological assessment was carried out under a microscope with a magnification of 400 times. Then, the mean weight of the liver histopathological change score was calculated in five fields of each mouse using the Manja Roenigk Histopathology Scoring model [15]. The hepatic structures observed were normal hepatocytes and hepatocytes that have both necrosis, parenchymal degeneration, and hydropic degeneration. Then, recorded and counted the percentage of damage that occurred.

\section{Molecular docking study}

A research conducted by Pasaribu in 2020 reported the results of the phytochemical analysis of Saurauia having bioactive compounds, namely, 3.19-Dihydroxyurs-12-en-28-oic acid; cis-3-O-phydroxycinnamoyl ursolic acid; corosolic acid; maslinic acid; and genistein. These compounds were evaluated for molecular interactions between target proteins involved in the inflammatory process and oxidative stress. This was done to further analyze the molecular mechanism of the hepatoprotective activity of pirdot leaves [16]

The target proteins involved in the production of reactive oxygen species were TNF- $\alpha$ (PDB: 2AZ5), cyclooxygenase 2 (COX-2) with ibuprofen as an antiinflammatory drug (PDB: 4PH9) [17], [18]. The ligand, a bioactive compound of pirdot leaves, was obtained from the PubChem database. Energy minimization was carried out in it using the mmff94, and docking with AutoDock Vina. Visualization of molecular interactions was carried out with the Chimera and Protein Plus database.

\section{Data analysis}

The experimental design used in this study was a completely randomized design. Twenty-four laboratory rats were grouped into four groups: The control group was given distilled water $\left(\mathrm{G}_{0}\right)$, the treatment group was given SRBC $\left(G_{1}\right)$, the treatment group was given pirdot lead ethanol extract (EEP) $\left(G_{2}\right)$, and the treatment group was given pirdot leaf extract $(E E P)+\operatorname{SRBC}\left(G_{3}\right)$. The obtained data were analyzed using Duncan's post-hoc test $(p<0.05)$, using Statistical Package for the Social Sciences version 24 software at an error rate of $5 \%$.

\section{Results}

\section{Analysis of SGOT and SGPT levels}

The measurement of the SGOT and SGPT values is presented in Table 1 . In this study, the SGOT 
levels in the $G_{1}, G_{2}$, and $G_{3}$ treatments were lower than the control. SGOT levels in the control treatment laboratory rats were at $248.27 \pm 58.75$ with the administration of SRBC decreased to $189.77 \pm 77.59$, and in the $G_{3}$ and $G_{2}$ treatments were $191.55 \pm 35.55$ and $196.60 \pm 24.37$, respectively. In this study, SGPT levels decreased significantly. SGPT in the control treatment was $121.74 \pm 7.62$, and SGPT in the $G_{2}$ and $\mathrm{G}_{3}$ treatments was $76.44 \pm 11.38$ and $55.50 \pm 15.75$. In the laboratory rats of the G1 treatment alone, the SGPT level increased to $214.00 \pm 15.34$.

Table 1: Effect of pirdot leaf ethanol extract on SGOT and SGPT values

\begin{tabular}{lll}
\hline Group & SGOT & SGPT \\
\hline Control $\left(G_{0}\right)$ & $248.27 \pm 58.75$ & $121.74 \pm 7.62^{*}$ \\
SDMD $\left(G_{1}\right)$ & $189.77 \pm 77.59$ & $214.00 \pm 15.34$ \\
EES $\left(G_{2}\right)$ & $196.60 \pm 24.37$ & $76.44 \pm 11.38^{*}$ \\
EES + SDMD $\left(G_{3}\right)$ & $191.55 \pm 35.25$ & $55.50 \pm 15.75^{\star \#}$ \\
\hline "Significantly different to G1 group (p<0.05), "Significantly different to G2 group $(p<0.05)$, SGPT: Serum \\
glutamic pyruvic transaminase, SGOT: Serum glutamic oxaloacetic transaminase, EES: Ethanolic extract of \\
pirdot leaves (S. vulcani Korth).
\end{tabular}

\section{Effect of EES on liver histology and level of hepatocyte damage}

According to the Kleiner research in 2018, the liver has a special pattern in indicating the condition of the liver tissue [19]. The pattern in the tissue indicates whether the degree of damage to the liver tissue was caused by the drug or not. Figure 1 visualizes that the histological observations of the liver of male laboratory rats found cell changes. The percentage of normal hepatocytes in the G1 group was the most compared to other treatments with a large number of cells experiencing swelling, hydropic, and necrosis.

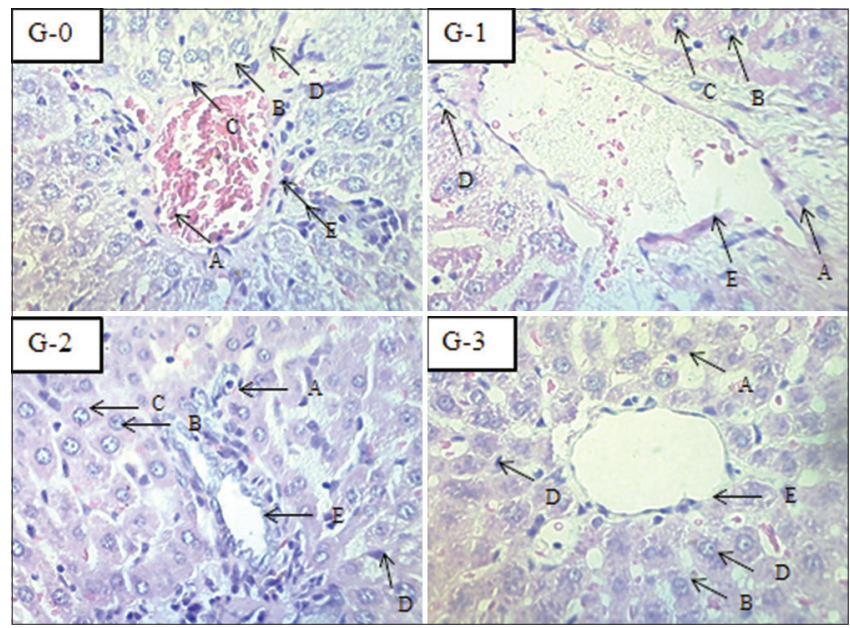

Figure 1: Histopathology of the liver of the test animal; G0: As a control (NA CMC), G1: Sheep red blood cells (SRBC), G2: Saurauia leaf ethanol extract (EES), and G3: EES + SRBC. (Magnification of $10 \times 40$ ) Description: (A) Normal, (B) parenchymptous degeneration, $(C)$ hydropic degeneration, $(D)$ necrosis, and $(E)$ central vein

The results of observations made on the microscopic image of the liver given SRBC and EES found normal hepatocytes and hepatocytes that had changes in the form of parenchymal degeneration, hydropic degeneration, and necrosis.

\section{In silico docking study}

The results of molecular docking of bioactive compounds of pirdot on COX-2 protein (PDB: 4PH9) and TNF- $\alpha$ protein (PDB: 2AZ5) are shown in Figures 2 and 3 . Table 2 shows the binding affinity of the molecular interactions of the compounds (ligand) on the target protein. The lowest and highest binding energies on the target protein of COX-2 (PDB: 4PH9) were found in pomolic acid $\left(-14.6 \mathrm{kcal} \mathrm{mol}^{-1}\right)$ and genistein $\left(-9.7 \mathrm{kcal} \mathrm{mol}^{-1}\right)$, respectively. Furthermore, the TNF- $\alpha$ protein target (PDB: 2AZ5) can be seen that the lowest binding energy was found in the cis-3-O-phydroxycinnamoyl ursolic acid $\left(-15.1 \mathrm{kcal} \mathrm{mol}^{-1}\right)$ and the highest was in genistein $\left(-8.6 \mathrm{kcal} \mathrm{mol}^{-1}\right)$. These findings were supporting previous studies [21], which stated that ursolic acid has significant potential in alcohol-induced liver protection as well as pomolic acid which is used as an anti-inflammatory [22].

\section{Discussion}

The data analysis presented in Table 1 shows that the decrease in SGOT levels was significant compared to the control group. The tendency of SGOT decreases in EES treatment showed the hepatoprotective properties of pirdot leaves. This is in line with a previous study conducted by Suryaningsih in 2017, where the administration of sambiloto extract did not affect hepatocyte function in laboratory rats [23]. This hepatoprotective property is shown by the decrease in SGOT in serum after administration of EES in serum.

SGPT levels in the $G_{2}, G_{3}$ and $G_{0}$ treated laboratory rats in this study decreased significantly compared to the SGPT levels of the $G_{1}$ treated rats. The lowest SGPT was found in the $\mathrm{G}_{3}$ and $\mathrm{G}_{2}$ treatment rats. The least significant difference test showed that the SGPT level of the rats in the $G_{3}$ treatment was significantly lower than the SGPT level in the EES treatment and control rats. The SGPT level of the $\mathrm{G}_{1}$ treatment rats was almost double the SGPT level of the control rats (Table 1).

The decrease in SGPT levels in the $\mathrm{G}_{2}$ and $\mathrm{G}_{3}$ treatments in this study showed the hepatoprotective properties of pirdot leaves. Thus, the liver function is well maintained and the immune system that is carried out by the liver runs well. The hepatoprotective properties of pirdot leaves are due to the presence of ursolic acid, which is closely related to liver protection. According to the research by $\mathrm{Ma}$ in 2020, administration of ursolic acid $20-80 \mathrm{mg} \mathrm{kg}^{-1} /$ day can reduce liver damage due to alcohol use [21].

The liver has an important function in innate and adaptive immunity. According to the research by Cai et al. in 2018, the liver contributes to the innate (non-specific) 


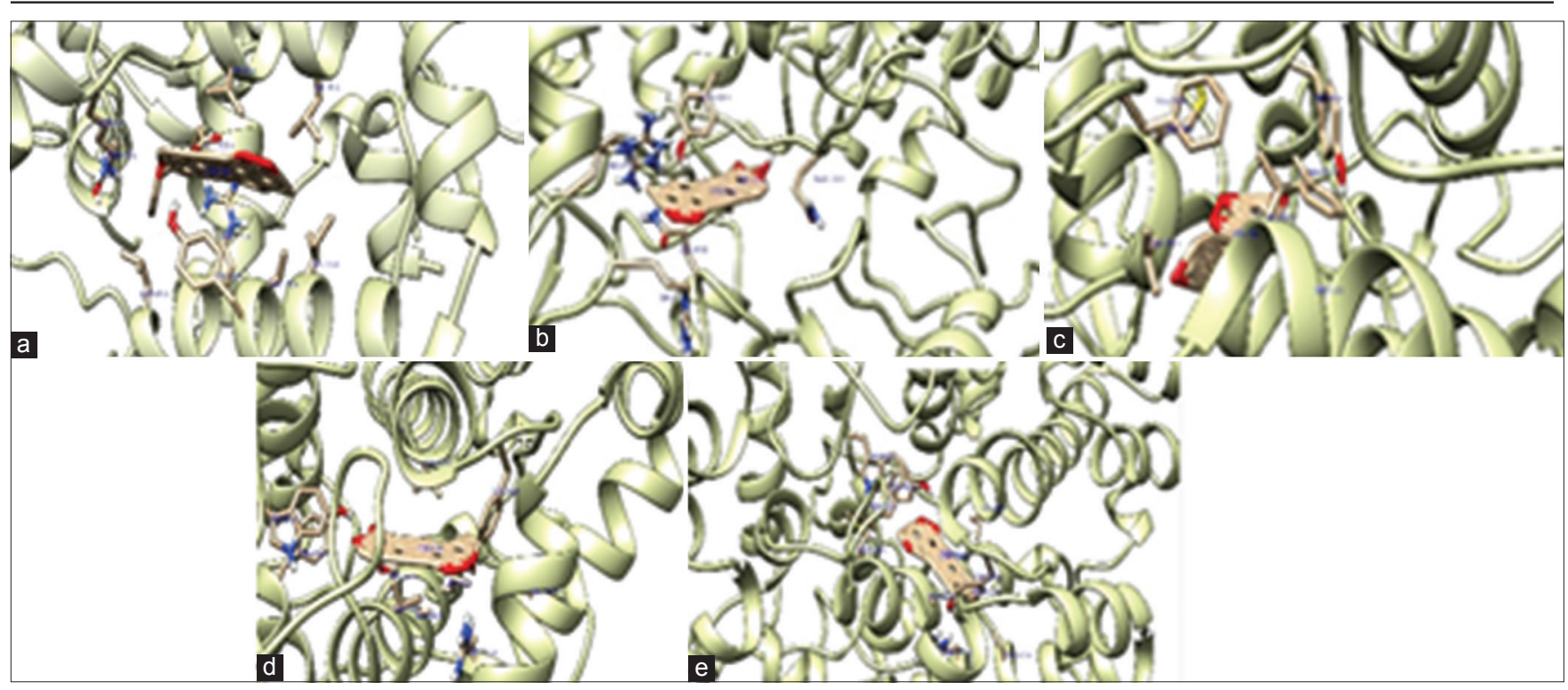

Figure 2: Molecular docking interaction between cyclooxygenase-2 protein (PDB: PDB: 4PH9) and bioactive compounds of pirdot leaf; (a) cis3-O-p-hydroxycinnamoyl ursolic acid; (b) corosolic acid; (c) genistein; (d) maslinic acid; and (e) pomolic acid, visualized using Chimera 1.14

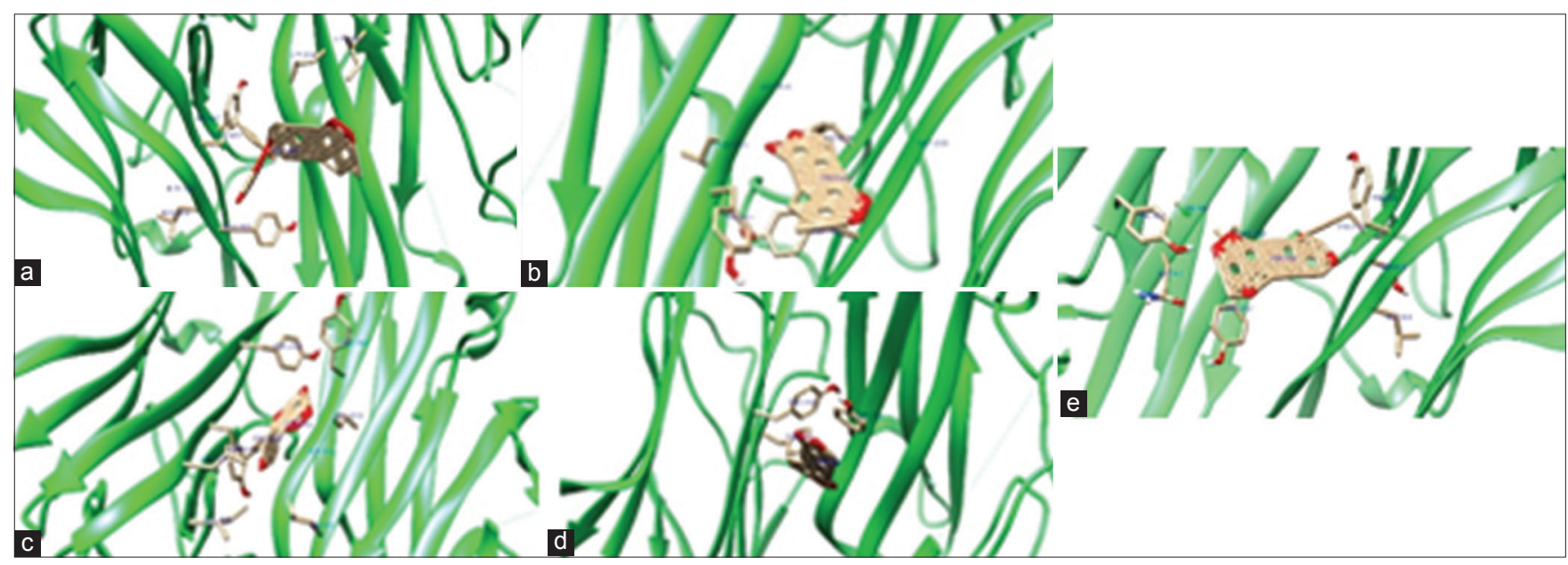

Figure 3: Molecular docking interaction between cyclooxygenase-2 protein (PDB: PDB: 4PH9) and bioactive compounds of pirdot leaf; (a) cis3-O-p-hydroxycinnamoyl ursolic acid; (b) corosolic acid; (c) genistein; (d) maslinic acid; and (e) pomolic acid, visualized using Chimera 1.14

immune system including the acute protein phase, nonspecific particle phagocytosis, non-specific molecular pinocytosis, and non-specific cell-killing [24].
Histological observation of the liver can be used to diagnose the level of damage to the liver, especially the level of damage to the hepatocytes [20]. The results

Table 2: The interaction of the protein bonds between COX-2 (PDB: 4PH 9) and TNF- $\alpha$ (PDB: 2AZ5) with bioactive compounds of pirdot

\begin{tabular}{|c|c|c|c|c|c|c|c|}
\hline \multirow[t]{2}{*}{ Bioactive compound } & \multicolumn{3}{|c|}{ COX-2 (PDB: 4PH 9) } & \multirow[t]{2}{*}{ Bioactive compound } & \multicolumn{3}{|c|}{ TNF- $\boldsymbol{\alpha}$ (PDB: 2AZ5) } \\
\hline & $\begin{array}{l}\text { Binding } \\
\text { affinity } \\
\text { (kcal/mol) }\end{array}$ & Hydrophobic interaction & Hydrogen bond & & $\begin{array}{l}\text { Binding } \\
\text { affinity } \\
{[\mathrm{kcal} / \mathrm{mol}]}\end{array}$ & $\begin{array}{l}\text { Hydrophobic } \\
\text { interaction }\end{array}$ & $\begin{array}{l}\text { Hydrogen } \\
\text { bond }\end{array}$ \\
\hline $\begin{array}{l}\text { cis-3-O- } \\
\text { p-hydroxycinnamoyl } \\
\text { ursolic acid }\end{array}$ & -14.1 & $\begin{array}{l}\text { Pro84A, Val89A, Leu93A, } \\
\text { Ile113A, Tyr116, and } \\
\text { Leu124A }\end{array}$ & $\begin{array}{l}\text { Lys83A, Arg121A, } \\
\text { Phe471A, and Glu525A }\end{array}$ & $\begin{array}{l}\text { cis-3-O-p-hydroxycinnamoyl } \\
\text { ursolic acid }\end{array}$ & -15.1 & $\begin{array}{l}\text { Leu57A, Tyr59A, } \\
\text { and Tyr119B }\end{array}$ & Leu120B \\
\hline Corosolic acid & -13.6 & $\begin{array}{l}\text { Val350A, Leu353A, } \\
\text { Tyr356A, Phe519A, } \\
\text { Val524A, and Ala528A }\end{array}$ & $\begin{array}{l}\text { His90A, Leu353A, } \\
\text { Phe519A, and Ser531A }\end{array}$ & Corosolic acid & -13.6 & $\begin{array}{l}\text { Tyr59B, Tyr119A, } \\
\text { and Tyr119B }\end{array}$ & $\begin{array}{l}\text { Tyr119B, } \\
\text { Gly121A, } \\
\text { and Tyr151B }\end{array}$ \\
\hline Genistein & -9.7 & $\begin{array}{l}\text { Leu353A, Phe519A, and } \\
\text { Val524A }\end{array}$ & $\begin{array}{l}\text { Tyr386A, Gly527A, and } \\
\text { Ser531A }\end{array}$ & Genistein & -8.6 & Tyr59D & Tyr119C \\
\hline Maslinic acid & -14.0 & $\begin{array}{l}\text { Val350A, Tyr356A, } \\
\text { Leu360A, Trp388A, } \\
\text { Val524A, Ala528A, and } \\
\text { Leu532A }\end{array}$ & $\begin{array}{l}\text { Arg121A, Tyr356A, } \\
\text { Tyr386A, and Ser531A }\end{array}$ & Maslinic acid & -13.7 & $\begin{array}{l}\text { Tyr59B, Tyr119A, } \\
\text { and Tyr151B }\end{array}$ & $\begin{array}{l}\text { Ser60A and } \\
\text { Leu120B }\end{array}$ \\
\hline Pomolic acid & -14.6 & $\begin{array}{l}\text { Val117A, Val350A, } \\
\text { Tyr356A, Trp388A, } \\
\text { Phe519A, and Ala528A }\end{array}$ & $\begin{array}{l}\text { Tyr356A, Tyr386A, and } \\
\text { Ser531A }\end{array}$ & Pomolic acid & -14.6 & $\begin{array}{l}\text { Tyr119C and } \\
\text { Tyr119D }\end{array}$ & $\begin{array}{l}\text { Ser60D, } \\
\text { Leu120D, } \\
\text { and Tyr151C }\end{array}$ \\
\hline
\end{tabular}


of observations on the level of hepatocyte damage in each treatment with SRBC and pirdot leaf extract were statistically presented in Table 3 . The increase in cell death (necrosis) in the $G_{1}$ group with SRBC was $5.8 \%$, followed by the $\mathrm{G}_{3}$ group of $2.3 \%$. According to the research by Vinken in 2021, hepatocytes are the type of cells that make up most of the liver [25]. Hepatocytes are responsible for the central role of the liver in metabolic processes. These cells are located between the sinusoids that fill with blood and the bile ducts. Furthermore, another study argues that liver cell damage is rarely caused by a substance but often by a metabolic toxic substance [26]. The cell contained in the liver might be deposited and might also change [27].

Table 3: Cross tabulation results in the liver treatment of laboratory rats (Rattus norvegicus)

\begin{tabular}{llllll}
\hline Parameters & \multicolumn{2}{l}{ Group (\%) } & Total (\%) \\
\cline { 2 - 5 } & G0 & G1 & G2 & G3 & \\
\hline Normal & 21.3 & 7.0 & 20.8 & 19.0 & 68.0 \\
Degeneration of parenchymatose & 1.8 & 5.8 & 1.5 & 1.8 & 10.8 \\
Degeneration of hydropic & 1.5 & 6.5 & 1.8 & 2.0 & 11.8 \\
Necrosis & 0.5 & 5.8 & 1.0 & 2.3 & 9.5 \\
Total & 25.0 & 25.0 & 25.0 & 25.0 & 100.0 \\
\hline
\end{tabular}

According to the research by Kleiner in 2018, if the liver cells are damaged due to various factors, there will be a series of morphological changes in the liver cells. Some changes in the structure of the liver due to chemical compounds that can be seen under microscopic observation include inflammation, fibrosis, degeneration, and necrosis [28]. These changes can be sublethal, namely, degenerative or lethal in the form of necrotic [29]. After damaging the cell membrane, the toxic effects can also reach the nucleus and damage it, resulting in abnormal cell structure and eventually leading to necrosis [30]. Hepatocyte swelling only occurs in the mitochondria and endoplasmic reticulum due to stimulation that results in oxidation. In the treatment groups, the hepatocyte damage occurred possibly due to the influence of the treatment causing impairment of cell membrane permeability. The disruption of cell membrane permeability was due to the effect of the administration of pirdot leaf ethanol extract and SRBC where high content of pirdot leaf extract with triterpenoids [9] and flavonoids that interfere with free radicals [8] (Figure 1).

This is following the results of the in silico study using the molecular docking approach. Bioactive compounds from pirdot leaves which are triterpenoids such as ursolic acid, maslinic acid, and pomolic acid as well as genistein compounds which are included in the flavonoid class, have great potential in protecting the liver. These bioactive compounds have significant interactions on the target protein, namely, COX-2 and TNF- $\alpha$. Pomolic acid compounds in pirdot leaves have the lowest binding energy of $-14.6 \mathrm{kcal} \mathrm{mol}^{-1}$ in the bonding interaction with COX-2 protein (Table 2) which is shown in Figure 3. These compounds form hydrophobic interactions and hydrogen bonds in Tyr356A. Furthermore, the ursolic acid compounds in pirdot leaves also have a significantly low binding energy of $-14.1 \mathrm{kcal} \mathrm{mol}^{-1}$ by interacting with Arg121A on COX-2 protein. This is supporting the interaction of ibuprofen as a drug that interacts with the active site of the binding of Tyr356A and Arg121A COX-2 [17].

TNF- $\alpha$ is a cytokine released by kupffer cells in the liver in response to toxic agents that enter the body [31]. In this study, bioactive compounds from pirdot leaves (Figure 3 and Table 2) had a significant interaction on the active side of TNF- $\alpha$ protein [32]. Ursolic acid in pirdot leaves has a significantly lower binding affinity of $15.1 \mathrm{kcal} \mathrm{mol}^{-1}$ by forming the hydrophobic interaction of Tyr59A and hydrogen bonding Leu120B on the binding site of TNF- $\alpha$ protein, which is following the finding of a previous study reported by Kumar et al. [33].

\section{Conclusion}

The potential hepatoprotective activity of pirdot leaf extract gave significant results both in vivo and in silico. A significant decrease in SGOT and SGPT values can be seen in the group given pirdot leaf ethanol extract. This is also supported by the in silico approach through molecular docking. Bioactive compounds from pirdot leaves such as pomolic acid and ursolic acid can inhibit the binding active side of COX-2 and TNF- $\alpha$ protein with significant binding affinity and molecular interactions, namely, hydrophobic interactions and hydrogen bonds formed on the binding active site of the target protein.

\section{References}

1. Ilyas U, Katare DP, Aeri V, Naseef PP. A Review on hepatoprotective and immunomodulatory herbal plants. Pharmacogn Rev. 2016;10(19):66-70. https://doi. org/10.4103/0973-7847.176544

PMid:27041876

2. Ju C, Phillips E, Holt MP, Gao YR, Lammert C.The adaptive immune system and liver toxicity. In: Third E, editor. McQueen CABT-CT. Oxford: Elsevier; 2018. p. 346-67. https://doi. org/10.1016/b978-0-12-801238-3.95663-0

3. Villanueva-Toledo JR, Chale-Dzul J, Castillo-Bautista C Olivera-Castillo L, Rangel-Méndez JA, Graniel-Sabido MJ, et al. Hepatoprotective effect of an ethanol extract of Tradescantia pallida against CCl4-induced liver damage in rats. S Afr J Bot. 2020;135:444-50. https://doi.org/10.1016/j.sajb.2020.09.031

4. TarasenkoTN, McGuirePJ. Theliveris ametabolicand immunologic organ: A reconsideration of metabolic decompensation due to infection in inborn errors of metabolism (IEM). Mol Genet Metab. 2017;121(4):283-8. https://doi.org/10.1016/j.ymgme.2017.06.010 PMid:28666653

5. Horst AK, Neumann K, Diehl L, Tiegs G. Modulation of liver tolerance by conventional and nonconventional antigenpresenting cells and regulatory immune cells. Cell Mol Immunol. 
2016;13(3):277-92. https://doi.org/10.1038/cmi.2015.112 PMid:27041638

6. Shah VV, Shah VK, Sheth NR, Patel MM. Hepatoprotective and Anti-inflammatory activities of hydroalcoholic extract of bark of Erythrinaindica. ResJPharmacolPharmacodyn2017;9(4):189-94. https://doi.org/10.5958/2321-5836.2017.00033.7

7. Babu G, Shalima NK, Divya TA. Evaluation of hepatoprotective activity of rhizomes of Curculigo orchioides Gaertn. Res J Pharm Technol. 2013;6(10):1127-30.

8. Sitorus P. Characterization simplisia and ethanolic extract of pirdot (Saurauia vulcani, Korth) leaves and study of antidiabetic effect in alloxan induced diabetic mice. Int J Chemtech Res. 2015;8:789-94.

9. Situmeang BR, Suparman AR, Kadarusman M, Parumbak AS, Herlina T. Isolasi senyawa triterpenoid dari ekstrak etil asetat pirdot (Saurauia vulcani. Kurth). J Kim Valensi. 2018;4(2):93-7.

10. Lovena TN, Harahap U, Sitorus P, Satria D. Antioxidant activity and $\alpha$-glucosidase inhibition effect of water extract Saurauia vulcani Korth leaves. J Innov Pharm Biol Sci 2018;5(3):47-51.

11. Sinaga E, llyas S, Hutahaean S, Sitorus P. Immunostimulatory activity from pirdot leaves ethanolic extract (Saurauia vulcani Korth.) in Rats (Rattus norvegicus). IOP Conf Ser Earth Environ Sci. 2019;305(1):012082. https://doi. org/10.1088/1755-1315/305/1/012082

12. Kumar Gupta R, Swain SR, Sahoo J, Gupta A, Chaudhary S. Hepatoprotective potential of Trichosanthes dioica Roxb in hepatotoxicity induced by simvastatin and its consequences on biochemical and haematological indices. Pharmacogn $\mathrm{J}$ 2018;10(4):720-4. https://doi.org/10.5530/pj.2018.4.120

13. Araya EM, Adamu BA, Periasamy G, Sintayehu B Gebrelibanos Hiben M. In vivo hepatoprotective and In vitro radical scavenging activities of Cucumis ficifolius $\mathrm{A}$. rich root extract. J Ethnopharmacol. 2019;242:112031. https://doi. org/10.1016/j.jep.2019.112031

\section{PMid:31220599}

14. Vasanthkumar T, Hanumanthappa M, Hanumanthappa SK Hepatoprotective effect of curcumin and capsaicin against lipopolysaccharide induced liver damage in mice. Pharmacogn J. 2017;9(6):947-51. https://doi.org/10.5530/pj.2017.6.148

15. Rongngern $P$, Chularojanamontri $L$, Wongpraparut $C$, Silpa-Archa $\mathrm{N}$, Chotiyaputta W, Pongpaibul A, et al. Diagnostic performance of transient elastography for detection of methotrexate-induced liver injury using Roenigk classification in Asian patients with psoriasis: A retrospective study. Arch Dermatol. 2017;309(5):4038. https://doi.org/10.1007/s00403-017-1733-4 PMid:28303329

16. Pasaribu G, Budianto E, Herry C, Saepudin E. A review on genus saurauia: Chemical compounds and their biological activity. Pharmacogn J. 2020;12:657-66. https://doi.org/10.5530/ pj.2020.12.97

17. Orlando BJ, Lucido MJ, Malkowski MG. The structure of ibuprofen bound to cyclooxygenase-2. J Struct Biol. 2015;189(1):62-6. https://doi.org/10.1016/j.jsb.2014.11.005 PMid:25463020

18. Khanal P, Patil BM. In vitro and in silico anti-oxidant, cytotoxicity and biological activities of Ficus benghalensis and Duranta repens. Chin Herb Med. 2020;12(4):406-13. http://doi. org/10.1016/j.chmed.2020.02.004

19. Kleiner DE. Histopathological challenges in suspected druginduced liver injury. Liver Int. 2018;38(2):198-209. https://doi. org/10.1111/liv. 13584

PMid:28865179

20. Roth NC, Qin J. Histopathology of alcohol-related liver diseases. Clin Liver Dis. 2019;23(1):11-23. https://doi.org/10.1016/j. cld.2018.09.001

PMid:30454825
21. Ma X, Zhang M, Fang G, Cheng $C$, Wang M, Han $Y$, et al. Ursolic acid reduces hepatocellular apoptosis and alleviates alcohol-induced liver injury via irreversible inhibition of CASP3 in vivo. Acta Pharmacol Sin. 2020;42(7):1101-10. http://doi. org/10.1038/s41401-020-00534-y PMid:33028983

22. Dzoyem JP, Nganteng DN, Melong R, Wafo P, Ngadjui B, Allémann $\mathrm{E}$, et al. Bioguided identification of pentacyclic triterpenoids as anti-inflammatory bioactive constituents of Ocimum gratissimum extract. J Ethnopharmacol. 2021;268:113637. https://doi.org/10.1016/j.jep.2020.113637

23. Suryaningsih NM, Dewi IA, Suksmawati NK, Putri NP, Febrianti NM, Warditiani NK. Pengaruh kadar SGOT SGPT dan morfologi hepar tikus putih betina wistar pada pemberian isolat andrografolid. J Farm Udayana. 2017;6(1):34-8.

24. Cai J, Zhang XJ, Li H. Role of innate immune signaling in non-alcoholic fatty liver disease. Trends Endocrinol Metab. 2018;29(10):712-22. https://doi.org/10.1016/j.tem.2018.08.003

25. Vinken M. Primary hepatocyte cultures for liver disease modeling. Curr Opin Toxicol. 2021;25:1-5. https://doi. org/10.1016/j.cotox.2020.08.003

26. Goodla L, Manubolu M, Pathakoti K, Poondamalli PR. Preventive and curative effects of Cocculus hirsutus (Linn.) Diels leaves extract on $\mathrm{CCl} 4$ provoked hepatic injury in rats. Egypt J Basic Appl Sci. 2017;4(4):264-9. https://doi.org/10.1016/j.ejbas.2017.10.004

27. Oke GO, Abiodun AA, Imafidon CE, Monsi BF. Zingiber officinale (Roscoe) mitigates CCl4-induced liver histopathology and biochemical derangements through antioxidant, membranestabilizing and tissue-regenerating potentials. Toxicol Rep. 2019;6:416-25. https://doi.org/10.1016/j.toxrep.2019.05.001 PMid:31193041

28. Yamakawa Y, Doi T, Naitou Y, Kawai H, Mitsumoto A, Kudo N, et al. A single pretreatment with clofibric acid attenuates carbon tetrachloride-induced necrosis, but not steatosis, in rat liver. Food Chem Toxicol. 2020;145:111591. https://doi.org/10.1016/j. fct.2020.111591

29. Rashidi N, Khatibjoo A, Taherpour K, Mohammad AG, Shirzadi H. Effects of licorice extract, probiotic, toxin binder and poultry litter biochar on performance, immune function, blood indices and liver histopathology of broilers exposed to aflatoxin-B1. Poult Sci. 2020;99(11):5896-906. https://doi. org/10.1016/j.psj.2020.08.034

30. Li M, Zhou Y, Zuo L, Nie D, Li X. Dietary fiber regulates intestinal flora and suppresses liver and systemic inflammation to alleviate liver fibrosis in mice. Nutrition. 2021;81:110959. https:// doi.org/10.1016/j.nut.2020.110959

PMid:33059126

31. Galani BR, Owona BA, Chuisseu DP, Machewere E, Ngantchouko CB, Moundipa PF. Hepatoprotective activity of Leptadenia hastata (Asclepiadaceae) on acetaminopheninduced toxicity in mice: In vivo study and characterization of bioactive compounds through molecular docking approaches. Biomed Res Int. 2020;2020:3807234. https://doi. org/10.1155/2020/3807234

PMid:32953880

32. Youssef FS, Ashour ML, Sobeh M, El-Beshbishy HA, Singab AN, Wink M. Eremophila maculata-isolation of a rare naturallyoccurring lignan glycoside and the hepatoprotective activity of the leaf extract. Phytomedicine. 2016;23(12):1484-93. https:// doi.org/10.1016/j.phymed.2016.08.006 PMid:27765369

33. Kumar PP, Krishnaswamy G, Desai NR, Sreenivasa S, Kumar DB. Design, synthesis, PASS prediction, in-silico ADME and molecular docking studies of substituted-(Z)-3-benzylidine5-aza-2-oxindole derivatives (Part-1). Chem Data Collect. 2021;31:100617. https://doi.org/10.1016/j.cdc.2020.100617 